\title{
НАЦІОНАЛЬНА ВИРАЗНІСТЬ ПОРТРЕТІВ ПЕТРА ХОЛОДНОГО-СТАРШОГО
}

\footnotetext{
У статті досліджується та частина портретного доробку Петра Холодного-старшого, яка характери-
} зується синтезом давньої портретної традииї зі стильовими новаціями українського мистецтва початку ХХ століття, яскраво демонструє національну виразність украӥнського мистецтва у зазначеному жанрі. Аналіз портретів Холодного-старшого у світлі згаданої проблеми проводиться вперше і є важливим для розуміння загальної авторської ідейно-стилістичної концепиії наџіонального мистецтва Петра Холодного-старшого в контексті української культури початку ХХ століття.

У світлі запропонованої теми розглянуто дівочі образи украӥнок і портрети військових, які брали участь в начіонально-визвольних змаганнях 1917-1920-х років. Визначено, щуо спільним для них є прагнення через індивідуальне передати характерне, типове, щчо уособлює українських дух. Підсилюючи національне звучання, певні образи мають бівалентне прочитання. Досліджено образно-стилістичні особливості ичих портретів $i$ їх зв'язок із давньою украйнською портретною традицією. Визначено, щуо при зображенні військових Петро Холодний-старший, втілюючи ідею героїчної боротьби і прагнучи показати ї̈ наступництво від часів козаџтва до сучасності, візуально звертається до авторської інтерпретаиії козацьких портретів минулого (литаючи лірико-поетичне й камерне для жіночих портретів).

Серед джерел «традииї» увагу акцентовано на зверненні до портретів парсунного типу (традииї давнього украӥнського портретного живопису), які здебільшого поширилися від канонів іконопису й одночасно зберігали народну естетику. Їх риси, композиційні схеми щцоразу по-різному інтерпретує Петро Холодний-стариий: то поєднуючи з реалістичною трактовкою чи спрощено-декоративною, то зі стилістикою модерну. Це дозволило Холодному-стариому вибудувати національну лінію у иъьому жанрі від сучасності до давнини. Важливо, щзо у зазначеній лінії прослідковується визначальна для всієї творчості Петра Холодного-старшого основа - середньовічне мистеитво.

Ключові слова: портрет, композиція, традиція, портрет-живопис, модернізм, стилістика, оригінальна кониุепція.

Olha SOBKOVYCH, orcid.org/0000-0002-6407-2527

Senior Researcher

National Museum "Kyiv Art Gallery"

(Kyiv, Ukraine) olga.sobkovych@gmail.com

\section{NATIONAL DISTINCTIVENESS OF THE PORTRAITS BY PETRO KHOLODNYI SR.}

The article examines the part of the portrait heritage by Petro Kholodnyi Sr., which is marked with the synthesis of the ancient portrait tradition and stylistic innovations of the Ukrainian art at the early twentieth century, clearly demonstrates the national distinctiveness of the Ukrainian art in the this genre. The analysis of portraits by Kholodnyi Sr. in the light of the mentioned problem is done for the first time and is important for understanding the general original ideological and stylistic national art concept of Peter Kholodny Sr. in the context of Ukrainian culture at the early twentieth century.

In the view of the offered topic, the maiden images of Ukrainian women and portraits of soldiers who took part in the 1917-1920 national liberation struggles are considered. It is determined that the feature they have in common is a desire to convey the peculiar, typical aspect that embodies the Ukrainian spirit, through the individual one. The image and stylistic features of these portraits and their reference to the ancient Ukrainian portrait tradition are also studied. Among the sources of "tradition" we can highlight the appeal to the painted portraits (on boards) type (Cossack painted portraits), which mainly followed the principles of icon painting and, at the same time, preserved the folk aesthetics.

Their features, compositional schemes are interpreted every time in the various ways by Petro Kholodnyi (sometimes combined with the realistic interpretation or primitive-decorative one, sometimes with the style of modernism), filling them with new ideas. This allowed Kholodnyi Sr. to create the national line in this genre from modernity (early twentieth century) to antiquity. It is symbolic that Petro Kholodnyi Sr. refers to the mentioned tradition only in the depiction of the military men, leaving the lyrical-poetic and intimate for female portraits.

Key words: portrait, composition, tradition, portrait-painting, modernism, stylistics, original concept. 
Постановка проблеми. Оскільки у власній творчості Петро Холодний-старший ставив за мету ствердження українського національного мистецтва, важливим є висвітлення шляхів його досягнення у різних видах і жанрах мистецтва, до яких він звертався. Варто розглянути національну виразність портретного доробку автора, який нині залишається майже недослідженим. Розгляд цього жанру у світлі згаданої проблеми досі не проводився, але він важливий для розуміння загальної авторської ідейно-стилістичної концепції національного мистецтва початку XX століття.

Аналіз досліджень. Нині немає грунтовного мистецтвознавчого дослідження портретної спадщини Петра Холодного-старшого. Окремі стислі, але влучні відгуки про цей жанр у творчості художника розміщені в публікаціях київських $\mathrm{i}$ львівських часописів початку XX століття. Здебільшого вони мають загальний характер і стосуються короткого розгляду якогось одного твору.

Досить оглядова інформація (буквально однедва речення) вміщена й на сторінках загальних праць 3 історії української культури та мистецтва зазначеного періоду, які виходили з 1991 року. Так, в «Історії української культури» 2005 року В. Рубан наводить тільки короткі відомості: «У портретних творах художник, з огляду на специфіку жанру, дотримувався безпосередності сприйняття і трактування образу моделі» (Рубан, 2005: 943). Згадка про цей жанр міститься і у статті О. Сидора «Петро Холодний-старший: киянин, який став львів'янином» 2006 року. У ній автор дає точну мистецтвознавчу оцінку, виділяючи характерне на прикладі портрету «Жінка 3 книгою»: «... він сприймається вдалим варіантом тематичного портрета камерно-ліричного звучання 3 типовою для автора внутрішньою зосередженістю художнього образу» (Сидор, 2006: 139).

Найбільш грунтовний огляд портретної спадщини художника 1920-х років (але лише образів військових) містить публікація О. СемчишинГузнер «Портрети керівників урядів УНР, ЗУНР і старшини армії УНР у творчості Петра Холодного і Юлія Магалевського» 2014 року. Автор звертає особливу увагу на корпус фактологічного матеріалу, який містить згадки про експонування портретів обох митців, їх перелік і долю. Наводяться й відгуки сучасників про доробок митців. Оскільки портретів Петра Холодного не збереглося, «цінним $\epsilon$ кожне слово чи $<\ldots>$ давня фотографія або чорно-біла репродукція в періодиці початку ХХ століття» (Семчишин-Гузнер, 2014: 118).

Важливо, що за згадками сучасників наведено опис вдачі та характеру учасників національно- визвольних змагань, прослідковано, як вирішено ïх образ у портретах Петра Холодного-старшого. Мистецтвознавчий аналіз досить стислий, проте авторка, аналізуючи композицію, слушно зазначає, що портрети «нагадують давні українські парадні портрети камерного вирішення», «козацькі портрети минулого» (Семчишин-Гузнер, 2014: 119-120). Як бачимо, на часі більш детальний розгляд портретного доробку; його мистецтвознавчий аналіз, визначення характерних рис, різновиди й типологія портретного жанру у творчості Петра Холодного-старшого, а також аналіз візуальнопластичної різноманітності рішення образів.

Мета статті полягає у висвітленні національної виразності портретного доробку Петра Холодного-старшого. Досліджено образно-стилістичні особливості портретів, які в сучасних формах передаються через авторську інтерпретацію української портретної традиції, зокрема давні парсуни, створюють осібну лінію у творчості митця.

Виклад основного матеріалу. Створені протягом усього творчого життя дитячі й жіночі образи, портретна галерея визначних українських діячів $\epsilon$ зразками високої художньої культури і майстерності художника, демонструють розмаїття творчого виконання. Візуально-стилістичне вирішення того чи іншого портрету - це не лише портретна схожість, а й вияв ідеї, суті певного образу, що наявно у творчості Петра Холодного-старшого. Про це влучно зазначив М. Вороний: «Цінність портретів полягає в тім, що, крім зверхньої подібності до їх моделей, вони викривають ще й духовний зміст - душу, характер, для чого артист уміє застосувати відповідну техніку» (Ноmo, 1922: 86).

Створені ним портрети демонструють розмаїття виконання, вирішення як стилістичного, так і технічного, де матеріал, фактура, кольорове та композиційне рішення - важливі засоби виразності. Ось як про це писав Драган, акцентуючи увагу на тому, що Петру Холодному однаково важливо, «що» і «як» писати: «Це «як» і «що» найкраще видно 3 його портретів, де він відповідно до теми регулює техніку чи фактуру мальовила. Інакше трактовані портрети військових, повні рішучості, характеризовані та стилізовані обличчя, - інше стомлені, але 3 життєвою мудрістю в очах, портрети стариків, виконані, немов свого роду поентимістичною технікою, - a ще інакше жіночі портрети з ліричним, спокійним настроєм, у яких положений більший натиск на декораційну сторінку (Драган, 1996: 44).

Згадане вище $є$ характерним для всіх портретів митця. У них відбилися пластично-стилістичні живописні розмаїття часу. Тут можна говорити 
про олійні та акварельні портрети (насамперед жіночі) та композиційні портрети. В останніх бачимо характерний для кінця XIX - початку XX століття розвиток нових форм портрету через трансформацію традиційних типів і взаємодію із побутовим і пейзажним жанрами, «що сприяє розвиткові портрета-картини чи так званого композиційного портрета» (ІУК. Т. 4. Кн. 2, 2005: 929). Петро Холодний-старший зображує своїх героїв серед природи (часто за читанням чи за роботою), настрій якої $є$ продовженням емоційного стану персонажа. Це є характерною ознакою для портретного жанру зазначеного часу, коли колір, досягнення пленерного живопису стають домінантами для творення пластично-емоційного образу (ІУК. Т. 4. Кн. 2, 2005: 929).

У цій публікації ми акцентуємо увагу на тій осібній та яскравій лінії в портретній творчості Петра Холодного-старшого, яка втілює національну виразність образів і за формою, і за змістом. У ній бачимо не лише авторську інтерпретацію портретної традиції минулого, а й більш широке розуміння портретної форми, що починає слугувати втіленню авторської концепції щодо творення національного мистецтва, де сучасне поєднано з минулим.

Щодо традиції, то в деяких портретах бачимо апелювання до давніх парсун, які «вимагали дотримання канонізованих форм, що відповідали старовинним традиціям» (ІУК. Т. 4. Кн. 2, 2005: 664), тобто іконописним традиціям. На думку Петра Холодного-старшого, саме ікона «щиро, безпосередньо відбиває момент національний і момент часу» (Холодний, 1998: 6). Портрети Холодногостаршого, збагачуючись сучасною пластикою, продовжували значно трансформовані у XVIII столітті парсунні традиції (поява нової іконографічної схеми), глибинні традиції Середньовіччя. Так, «репрезентативні парадні (на зріст і погрудні) композиції і камерний портрет - основні іконографічні типи, властиві російському мистецтву XVIII століття, розвивав і вдосконалював у своїй творчості Д. Левицький» (Рубан, 1984: 22).

Розглянемо, як зазначена лінія виявляється у дівочих образах українок і портретах військових, спільним для яких $є$ прагнення через індивідуальне передати характерне, типове, що уособлює українських дух. Малюванням військових Петро Холодний-старший зацікавився, за згадками Софії Русової, ще у Вінниці. Велика кількість творів, особливо портретів військових, була створена у Тарнові, де Холодний-старший був змушений перебувати з Урядом УНР. Саме в портретах військових Холодний-старший передав дух наці- онально-визвольних змагань 1917-1921 років, ідею героїчної боротьби. Прагнучи показати наступництво цієї боротьби від часів козацтва до сучасності, візуально він звернувся до авторської інтерпретації козацьких портретів минулого. На жаль, зазначені портретні твори, які мають мистецьку та історичну цінність, втрачено. Про них ми говоримо лише за каталогами виставок 1920-1930-х років і чорно-білими репродукціями в періодиці.

У контексті поєднання сучасного і традиції розглянемо збережені за каталожними репродукціями твори: «Портрет генерал-хорунжого М. Безручка» (Холодний, 1931: 33), «Портрет генералхорунжого В. Сальського» (Літопис Червоної Калини, 1931: 1), «Портрети полковника Дмитра Вітовського», «Портрет генерал-хорунжого Михайла Омеляновича-Павленка» (Визволення, 1921: 16-17).

«Портрет генерал-хорунжого В. Сальського» за своїх вирішенням найбільше зберігає риси, характерні для «парсун» - портретних зображень періоду зародження та становлення жанру портрету на території України, які ще зберігали традиції іконопису. У вказаному портреті це виявляється в площинності трактування нейтрального тла, де лише горизонтальна лінія окреслює поділ простору. Такий прийом апелює до україно-візантійської традиції, яка не розв'язувала перспективноілюзіоністичної проблеми, підпорядковуючи все «двовимірній» площині, що і перейняла парсуна.

Портрет генерала-хорунжого Петро Холоднийстарший моделює об'ємно. За композиційним вирішенням постаті він наближений до козацьких портретів: гордовита постава генерала, де права рука зігнута на рівні поясу (подібний жест бачимо у деяких портретах В. Боровиковського, у ктиторських портретах братів Якова та Івана Шиянів 1781 року та портреті Козачого полковника П. Я. Руденка 1784 року). За композиційним вирішенням наближений до зазначеного портрету Сальського графічний портрет сина художника Петра Холодного-молодшого у військовій формі 1921 року. Тому можна говорити про єдиний принцип вирішення образів, але тут постать юного хлопця подана у три чверті (відомий портрет Івана Шияна 1781 року невідомого митця, якого також зображено у три чверті).

До парсун близьке й загальне візуально-стилістичне вирішення погрудного «Портрету генерал-хорунжого М. Безручка», який характеризується лаконізмом. Як і в портреті В. Сальського, військового зображено фронтально на нейтральному тлі, але до композиції включено напис лати- 
ницею "Marcus Bezrutschco gloriosae VI diwisionis exercitus Ucrainiensis praefectus" («Марко Безручко, командир славної VI дивізії українського війська»), що акцентує увагу на участі легендарного військового в одній із переломних битв Шостої Січової стрілецької дивізії в серпні 1920 року, яка спинила наступ більшовиків на Східну Європу (Семчишин-Гузнер, 2014: 120).

Варто зазначити, що включення написів у портретні та іконописні композиції - характерна риса українського мистецтва (ІУК, Т. 4. Кн. 2, 2005: 664), яка зустрічається, наприклад, у творчості відомого українського митця II половини XVIII століття В. Боровиковського, родина якого займалася іконописом. Як відомо, рід Холодних також мав іконописців по материнській лінії.

Своєю композиційною простотою та ясністю, монументальністю розташування образу в замкненому просторі згаданий портрет нагадує стримані й лаконічні портрети XV століття доби Північного Відродження.

У згаданого портрета $€$ ще одна важлива ознака, яка підсилює національне звучання. Вона втілена у бівалентному прочитанні візуального образу, про що влучно зазначив Ю. Магалевський, аналізуючи портрети Безручка та генерала Тютюнника. Він стверджував, що це - не просто

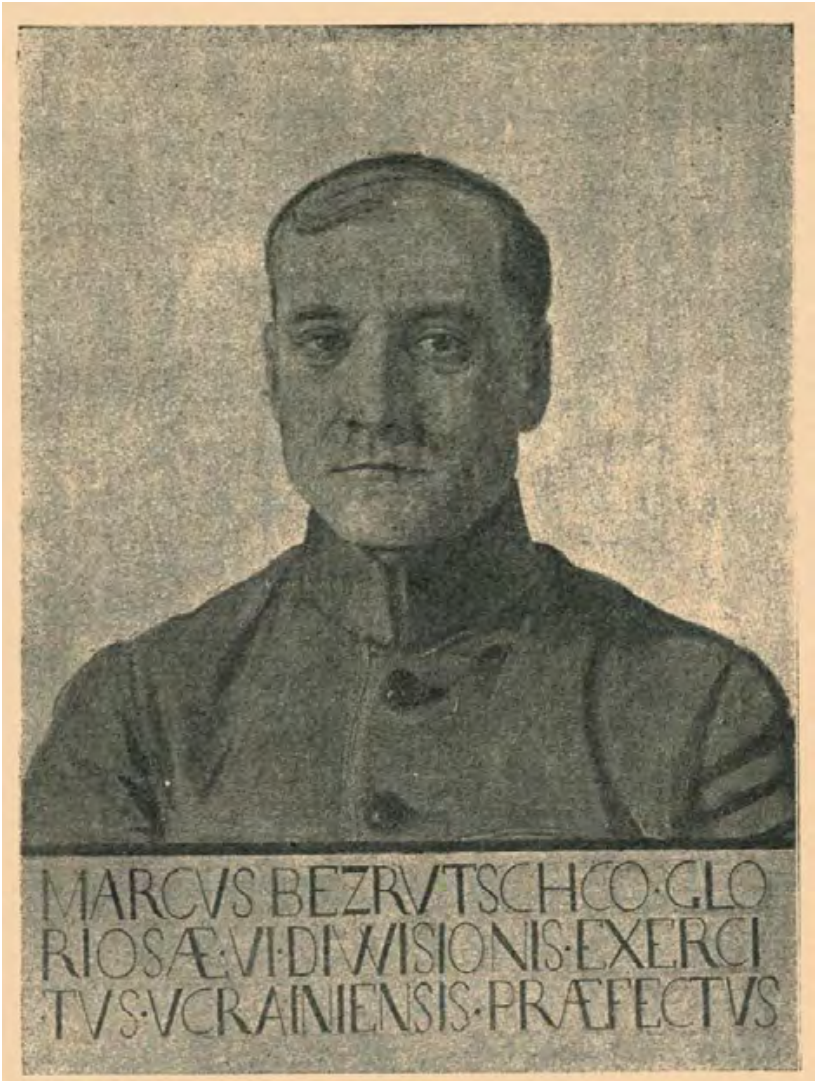

Рис. 1 портрети живої людини, які передають особисті риси характеру, а й «певного рода апофеози; але коли Базручко має безсмертність камінної статуїген. Тютюнин має щось із «характерника» - його життєва сила здається невичерпаною» (Магалевський, 1923: 2). Таким чином Холодному-старшому вдається створити портрети-образи, які поєднують індивідуальне й загальне, сучасне та давнє, передаючи ті емоції й характеристики, які інтуїтивно близькі українцю. У них закладена ідея, що живе доти, поки живе народ. «... портрет славного полковника (Безручка - О. С.) був неначе грандіозним символом, майже абстрактним образом епохи та покоління» (Магалевський, 1923: 2).

Функціональне розширення традиційного парадного портрету, його психологізація та стилістичне трактування відповідно до модерну, точніше «модерного візантизму», Петра Холодногостаршого зустрічаємо у «Портреті полковника Дмитра Вітовського». Згадаймо, що до пластичного переосмислення форм давнього репрезентативного портрету звертався й Ф. Кричевський (ІУК. Т. 4. Кн. 2, 2005: 941). Проте, на відміну від жіночих і чоловічих зображень Кричевського, в яких домінує монументально-величне звучання,

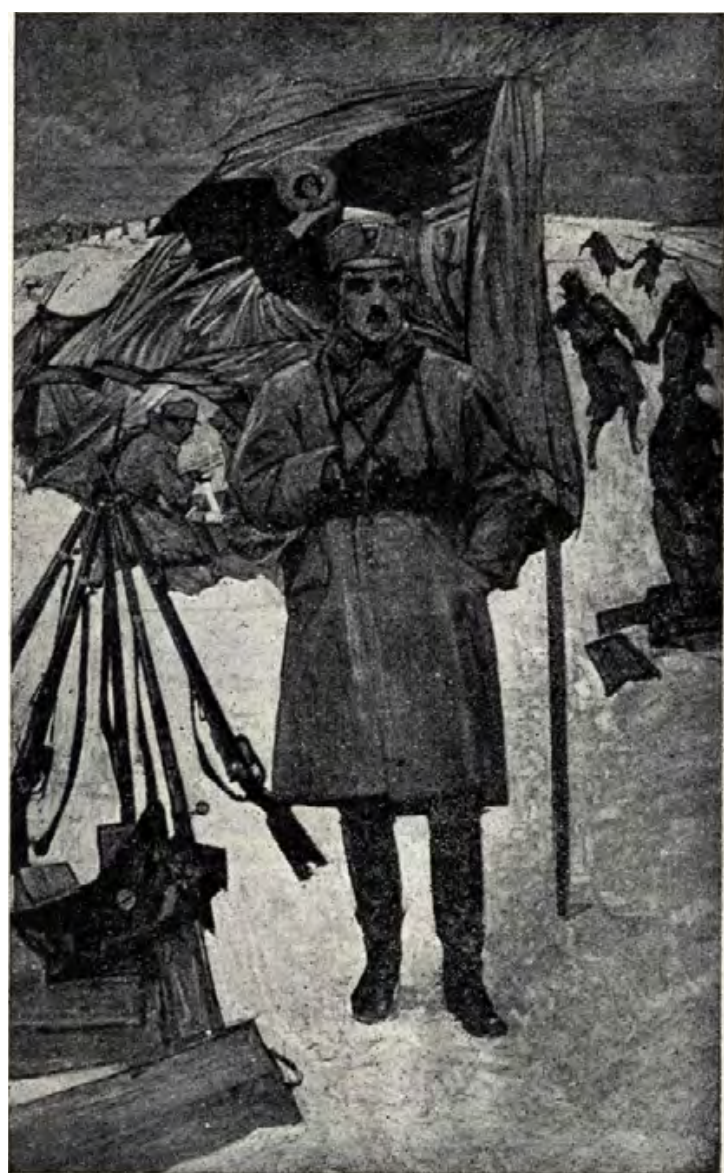

Pис. 2 
живописне моделювання, насиченість кольору, портрети Холодного-старшого позначені більшою як пластично-кольоровою, так і емоційною стриманістю розуміння та подачею образу. Символічно, що Петро Холодний-старший звертається до згаданої традиції лише у зображенні військових, лишаючи лірико-поетичне й камерне для жіночих портретів.

Від традиції Петро Холодний-старший бере трактовку пози героя: полковника зображено у повний зріст, фронтально в центрі композиції, його постать, жест суголосні портретові В. Сальського. Однак портрет Вітовського позбавлений тієї лаконічної простоти форм і статичності (характерної для парсун), яка домінує в композиціях Безручка та Сальського. Ї̈ї змінює динаміка та звернення до модерну.

Для передачі історичного військового часу картина ускладнена змалюванням бойових дій зимової пори (до композиції введено зображення вояків, зброї). Рішучий образ Вітовського зображено на тлі стягу, який вводиться до композиції Холодним, щоб сконцентрувати увагу на полковнику, умовно відділивши перший (спокійний) i другий (сповнений динаміки) плани. Такий прийом дозволив, здається, уповільнити час (і навіть зупинити його) для закарбування образу полковника Вітовського. Як зазначив О. Семчишин-Гузнер, це - портрет-пам'ятник, який було створено 1924 року вже після смерті Дмитра Вітовського 1919 року (Семчишин-Гузнер, 2014: 120).

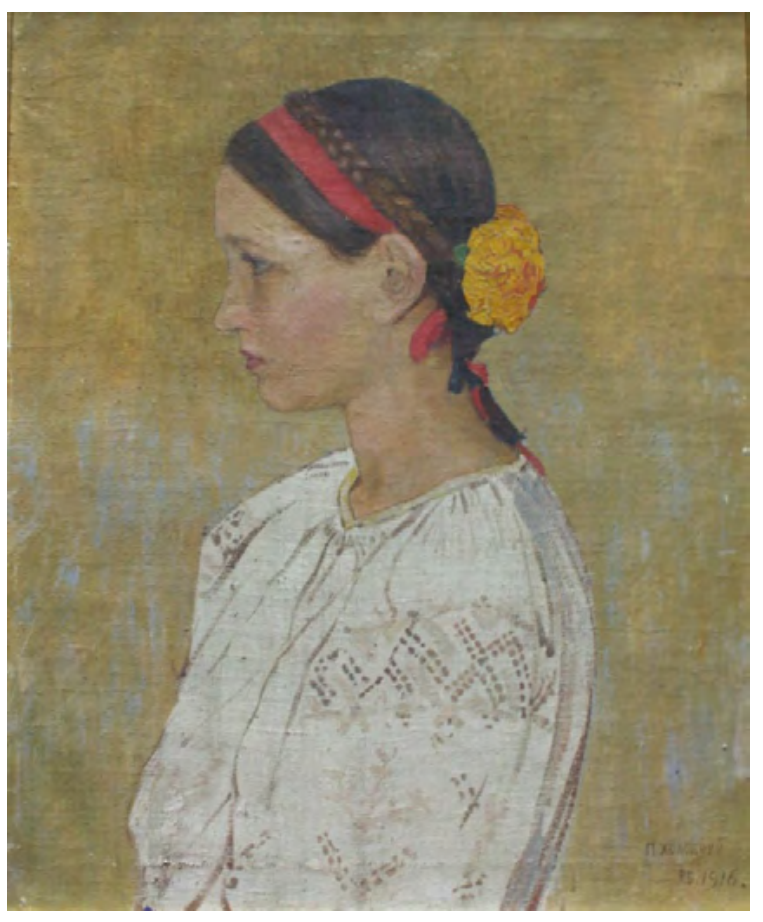

Рис. 3
За загальною композиційною схемою вирішення портрету можна провести паралель із репрезентативним українським портретом у митців середини та кінця XVIII століття, які виконували портрети на межі старих і нових форм: Володимира Боровиковського «Портрет П. Я Руденка» 1784 року, Михайла Іванова «Портрет Антона Головатого» 1792 року. Зазнаючи пластичних змін, «на українському грунті традиції давнього репрезентативного портрету вони простежуються аж до 60-х років XIX століття» (Рубан, 1984: 28). У Петра Холодного-старшого простежуємо тяглість традиції інтерпретації давнього портрету. У зображенні Дмитра Вітовського бачимо певну модерно-декоративну стилізацію, яка наявна в ритміці елементів композиції, подачі простору, у зображенні стягу, його ритмічно-графічній динаміці складок. У подібній подачі вгадуються риси, притаманні історичним та сакральним творам Петра Холодного.

У часописі «Визволення» за 1921 рік було надруковано два графічні портрети учасників національно-визвольних змагань. Один із них зображує найпопулярнішого із військових УНР генерал-хорунжого Михайла Омеляновича-Павленка. Його вирішення відповідає стилістиці модерну й $є$ силуетною графічною композицією (до портретних темних силуетів звертався іГ. Нарбут) портрету-картини, де образ героя розкривається через стилізоване змалювання конкретної військової події, що увійшла в українську історію під назвою «Перший зимовий похід». Дати початку та завершення походу введено до композиції (6 грудня 1919 року - 6 травня 1920 року). Саме ця героїчна військова подія закарбувала ім'я військового в українській історії, ставши 3 ним одним цілим. Тому не дивно, що Петро Холодний-старший обрав саме такий сюжет, що якнайкраще характеризує мужній образ генерал-хорунжого. Чорний силует профілю передає характерне у портреті військового, апелюючи до типового образу козака з вусами, а символіка (український тризуб) - акцентує увагу на меті боротьби. Характерні для Михайла Омеляновича-Павленка риси сконцентровано не стільки в портреті, як в його військовій діяльності, про що свідчать менші за розміром силуети військових. У композицію зображення введено й авторський підпис генерал-поручника.

Сповнені національної виразності й дівочі українські образи, до змалювання яких митець звертався у різні роки. Каталоги виставок дають таку інформацію: «Дівчина. Народний тип», 1907 рік; «Дівчина в народній одежі», 
1923 рік (Холодний, 1931: 11, 17); збережене фото з виставки 1911 року - відомий портрет дівчини в українському одязі на тлі пейзажу (судячи з каталожного переліку це має бути твір «Дочка»). Його можна вважати портретом у пленері (змалювання моделі серед природи було характерним для творчості митця). Сюди варто віднести й «Портрет дівчини» 1916 року.

Необхідно зазначити, що до змалювання селян зверталося багато митців зі Східної та Західної частин України; це було ознакою часу, коли і народне мистецтво, і народні образи ставали об'єктом зацікавлення митців. Кожен у них шукав та втілював своє. Петра Холодного ж, припускаємо, цікавило створення загального народного характеру української дівчини, сповненого поетичності та моральної чистоти. На жаль, два із зазначених вище творів не збереглися, але в контексті теми цього дослідження варто розглянути «Портрет дівчини» (1916 рік).

Портрет змальовує доньку художника Марію. Тут ми бачимо характерну для Петра Холодногостаршого просту композицію, стриманий колорит, лірико-поетичну трактовку внутрішньо зосередженого образу, що надає камерності звучання. Портрет було створено за мотивом фольклорної композиції «Казка про дівчину і паву» (1916 рік), що й пояснює його загальне кольорове вирішення, яке нагадує фресковий живопис і змалювання дівчини у вишиванці. Збереглися спогади доньки щодо цього: «В Студениках была так называємая комора, под навесом которой мы проводили много времени. Там папа писал мой портрет в украинском костюме. Было мне тогда семь лет» (Холодная, 1994: 88).

Оскільки зображення було створено під впливом народно-поетичної творчості, бачимо, що це не тільки портрет конкретної людини, а й узагальнений і поетизований образ молодої української дівчини. Звідси сприйняття цього портрету як лірико-поетичного національного портрету-типу, в якому поєднана імперсональність та індивідуальна характеристика. Цікавим $є$ те, що досить реалістична мова самого портрету, що апелює до традиції змалювання селянських образів, контрастує із нейтральним вохристо-золотим трактуванням тла, яке відповідає площинній іконопис- ній традиції. Зображення дівчини на золотому тлі характерне й для творчості М. Бойчука «Дівчина» (1900-ті роки). Однак ці два твори демонструють кардинально різне переосмислення традицій візантизму обома митцями.

Висновки. Суголосно часові національного культурного відродження України Петро Холодний-старший прагнув у власній творчості передати національне і сучасне, які мали ствердити самобутне українське мистецтво. Як і в інших видах i жанрах мистецтва, до яких звертався митець, у портреті Холодний-старший звертається до давньої традиції та її творчої інтерпретації, що поєднувала стилістичні новації того часу. Це відповідало авторській мистецькій концепції Холодного-старшого, який прагнув для відродження українського мистецтва, хотів «зробити ту роботу, яку провадили всі попередні покоління, передати свою добу через свою душу, але зробити так, щоб як і в них зоставався зв'язок між сучасним і попередніми часами» (Холодний, 1996: 6). Таке бачення шляху розвитку національної культури, мистецтва об'єднувало європейську та просвітницьку орієнтацію в одне ціле (як писав I. Труш «Ми повинні стояти нагами на нашій землі, головою бути у Європі, а руками охоплювати як можна ширше справи української нації») i було релевантне для часу модерну (Савицька, 2002: 376-377).

У портреті Петро Холодний-старший звертається до портретів парсуного типу, які здебільшого походили від канонів іконопису, та щоразу по-різному їх інтерпретує (поєднуючи то з реалістичною трактовкою, то зі стилістикою модерну). Це дозволяло Холодному-старшому вибудувати національну лінію в цьому жанрі від сучасності до давнини. Вказана лінія побудована на визначальній у творчості Петра Холодного-старшого основі - середньовічному мистецтві: стародавні фрески нагадують своїм колоритом його твори на фольклорні мотиви, створені у темперній техніці («Казка про дівчину і паву», «Ой у полі жито»), «візантизм» стає визначальним для творення ікон та сакрального монументального мистецтва (вітражі, розписи); у портреті спостерігаємо трактування композиції, витоки якої виходять із глибин Середньовіччя.

\section{СПИСОК ВИКОРИСТАНИХ ДЖЕРЕЛ}

1. Драган М. Мистецька творчість П. Холодного. На пошану Петрові Івановичу Холодному (1876-1930). Львів, 1996. Вип. 1. С. 42-44.

2. Історія української культури у 5 томах. Київ : Наукова думка, 2005. Т. 4. Кн. 2. 1266 с.

3. Лісовський Р. Петро Холодний (1876-1930). Прага : Видавництво української молоді, 1932. 16 с.

4. Літопис Червоної Калини. 1937. №№ 7-8. С. 1.

5. Магалевський Ю. Друга українська мистецька виставка. Діло. 1923. 27 травня. № 42. С. 2. 
6. Петро Іванович Холодний (1876-1930) : каталог посмертної виставки праць. Львів, 1931. 32 с.

7. Портрет М. Омеляновича-Павленка. Визволення. 1921. Чис. 1-2. Вкладка між с. 16-17.

8. Рубан В. Український портретний живопис першої половини ХІХ століття. К. : Наукова думка, 1984. 224 с.

9. Савицька Л. Народне мистецтво і художня культура на початку ХХ століття. Традиційне й особистісне у мистецтві. Київ, 2002. С. 375-380.

10. Семчишин-Гузнер О. Портрети керівників урядів УНР, ЗУНР і старшини армії УНР у творчості Петра Холодного та Юлія Магалевського. Літопис Національного музею у Львові ім. Андрея Шептицького. 2014. № 10 (15). С. $112-123$.

11. Сидор О. Петро Холодний-старший: киянин, який став львів’янином. Львів (1256-2006). Церква $i$ суспільство : статті і матеріали. Львів : Вид-во Львівського музею історії релігії «Логос», 2006. С. $136-142$.

12. Холодний П. Відповідь на запит. 25-ліття Національного музею у Львові. Львів, 1930. С. 4-5.

13. Холодная М. П. Воспоминания. М., 1994. 86 с.

14. Ното. 3 мистецької виставки (Вражіння і замітки). Літературно-науковий вісник. 1922. Кн. IV. C. 76-92.

\section{REFERENCES}

1. Drahan M. Mystetska tvorchist P. Kholodnoho. [Artistic work of P. Kholodny]. Na poshanu Petrovi Ivanovychu Kholodnomu (1876-1930). Lviv, 1996, Vyp. 1, p. 42-44 [in Ukranian].

2. Istoriia ukrainskoi kultury u 5 tomakh. [History of Ukrainian culture in 5 vols]. Kyiv : Naukova dumka, 2005. Vol. 4, book. 2. 1266 p. [in Ukranian].

3. Lisovskyi R. Petro Kholodnyi (1876-1930). [Petro Kholodnyi (1876-1930)]. Prague : Vydavnytstvo ukrainskoi molodi, 1932. 15 p. [in Ukranian].

4. Litopys Chervonoi Kalyny. 1937. №№ 7-8. P. 1 [in Ukranian].

5. Mahalevskyi Yu. Druha ukrainska mystetska vystavka. [The second Ukrainian art exhibition]. Dilo. 1923. № 42 (27 trav.). P. 2 [in Ukranian].

6. Petro Ivanovych Kholodnyi (1876-1930) : kataloh posmertnoi vystavky prats. [Peter Ivanovych Kholodny (18761930) : catalog of the posthumous exhibition of works.]. Lviv, 1931. 32 p. [in Ukranian].

7. Portret M. Omelianovycha-Pavlenka. Vyzvolennia. 1921. № 1-2. P. 16-17 [in Ukranian].

8. Ruban V. Ukrainskyi portretnyi zhyvopys pershoi polovyny XIX stolittia. [Ukrainian portrait painting of the first half of the XIX century]. K. : Naukova dumka, 1984. 224 p. [in Ukranian].

9. Savytska L. Narodne mystetstvo i khudozhnia kultura na pochatku XX stolittia. [Folk art and art culture in the early XX century]. Tradytsiine y osobystisne u mystetstvi. Kyiv, 2002. P. 375-380 [in Ukranian].

10. Semchyshyn-Huzner O. Portrety kerivnykiv uriadiv UNR, ZUNR i starshyny armii UNR u tvorchosti Petra Kholonoho ta Yuliia Mahalevskoho. [Portraits of the heads of governments of the Ukrainian People's Republic, the Western Ukrainian People's Republic and officers of the UPR army in the works of Peter Kholony and Yuliy Magalevsky]. Litopys Natsionalnoho muzeiu u Lvovi im. Andreia Sheptytskoho. 2014. № 10 (15). P. 112-123 [in Ukranian].

11. Sydor O. Petro Kholodnyi-starshyi: kyianyn, shcho stav lvivianynom. [Petro Kholodnyi-Senior: Kiev resident in Lviv]. Lviv (1256-2006). Tserkva i suspilstvo : statti i materialy. Lviv : Vyd-vo Lvivskoho muzeiu istorii relihii "Lohos", 2006. P. 136-144 [in Ukranian].

12. Kholodnyi P. Vidpovid na zapyt [Answer the request]. 25th anniversary of the National Museum in Lviv. Lviv, 1930. P. 4-5 [in Ukranian].

13. Kholodnaia M. P. Vospomynanyia. [Memories]. M., 1994. 86 p. [in Russian].

14. Homo. Z mystetskoi vystavky (Vrazhinnia i zamitky). [From the art exhibition (Impressions and notes)]. Literaturno-naukovyi visnyk. 1922. Kn. IV. C. 76-92 [in Ukranian]. 